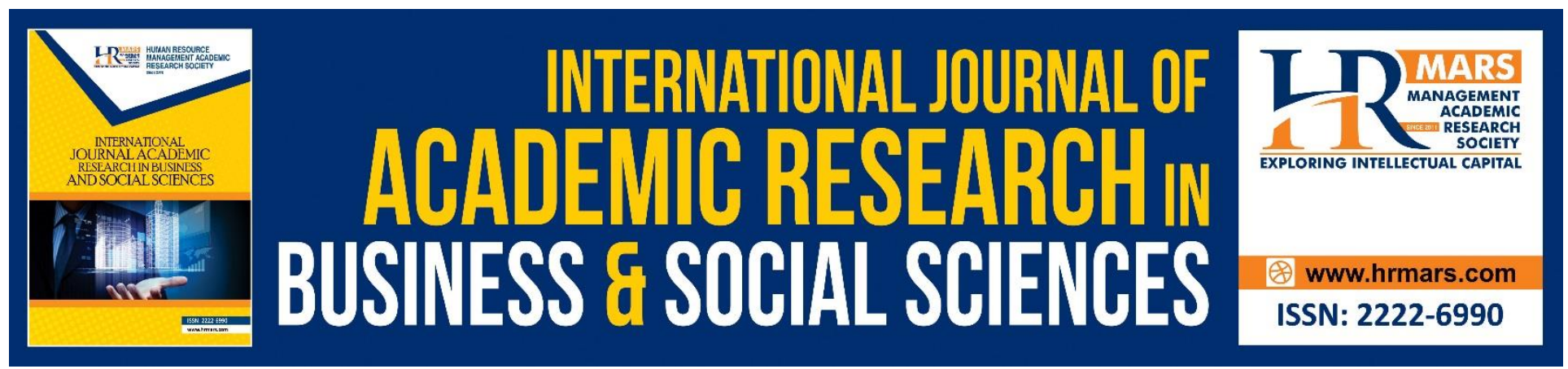

\title{
Enhancing the Management of 1AZAM Poverty Programme: Transforming the Poverty Groups into a Competitive Malaysian Society
}

Radieah Mohd Nor

To Link this Article: http://dx.doi.org/10.6007/IJARBSS/v10-i9/7748

DOI:10.6007/IJARBSS/v10-i9/7748

Received: 02 June 2020, Revised: 07 July 2020, Accepted: 12 August 2020

Published Online: 28 September 2020

In-Text Citation: (Nor, 2020)

To Cite this Article: Nor, R. M. (2020). Enhancing the Management of 1AZAM Poverty Programme: Transforming the Poverty Groups Into A Competitive Malaysian Society. International Journal of Academic Research in Business and Social Sciences. 10(9), 380-392.

\section{Copyright: (c) 2020 The Author(s)}

Published by Human Resource Management Academic Research Society (www.hrmars.com)

This article is published under the Creative Commons Attribution (CC BY 4.0) license. Anyone may reproduce, distribute, translate and create derivative works of this article (for both commercial and non-commercial purposes), subject to full attribution to the original publication and authors. The full terms of this license may be seen

at: $\underline{\text { http://creativecommons.org/licences/by/4.0/legalcode }}$

Vol. 10, No. 9, 2020, Pg. 380 - 392

http://hrmars.com/index.php/pages/detail/IJARBSS

JOURNAL HOMEPAGE

Full Terms \& Conditions of access and use can be found at http://hrmars.com/index.php/pages/detail/publication-ethics 


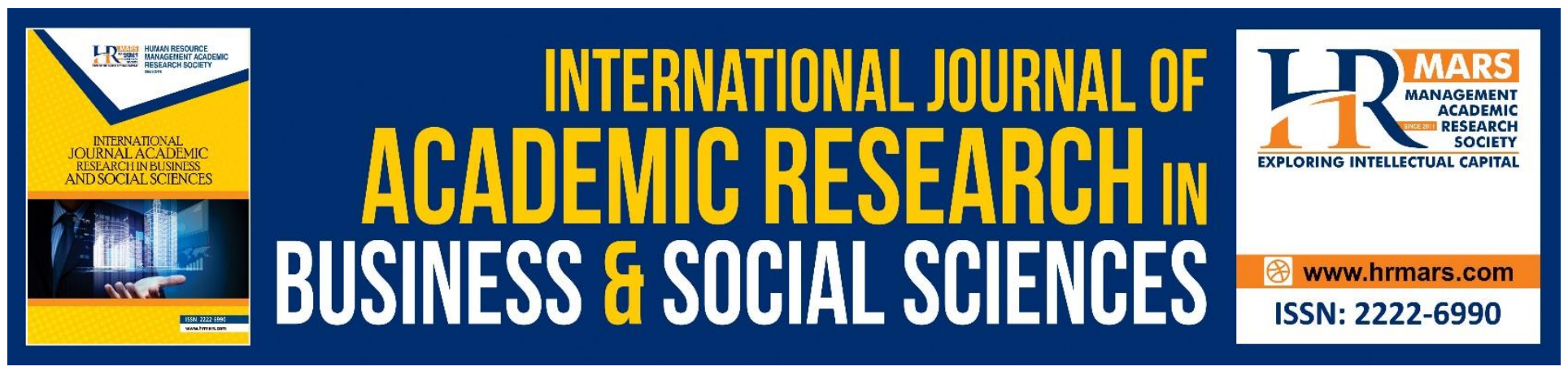

\title{
Enhancing the Management of 1AZAM Poverty Programme: Transforming the Poverty Groups Into A Competitive Malaysian Society
}

\author{
Radieah Mohd Nor \\ Center for Global Sustainability Studies, Universiti Sains Malaysia, Malaysia \\ Email: radieah@usm.my
}

\begin{abstract}
Malaysia aims to achieve developed nation status. Many actions have been taken, especially to eradicate poverty among the population. This paper aims to explore the government's challenges and limitations to eradicate poverty through its 1AZAM programme. 1AZAM is the Government's main initiative for eradicating poverty, starting in 2010. Its aim is to help the poor groups to increase their income, while simultaneously to move them out of the shackles of poverty. This study employed the qualitative approach and conducted open interviews with 100 participants selected using the random sampling method, to examine their conditions before and after participating in the 1AZAM programme. Interviews were also conducted with the Division of Distribution, Economic Planning Unit (EPU), and Division of People's Welfare, Implementation and Coordination Unit (ICU), Prime Minister's Department (JPM). Data analysed using textual analysis found that the challenges and constraints faced by the programme can be divided into four aspects. First, the Main Performance Index used was not consistent with the Official Poverty Line Income. Second, there is a lot of money wasted. Third, the eKasih system needs to be improved. Finally, the monitoring system was not thorough and holistic. All these four aspects need to be given attention by the implementing agencies so that the programme can produce a maximum impact on the target groups.
\end{abstract}

Keywords: Eradicate Poverty,1AZAM Programme, EKasih System.

\section{Introduction}

Malaysia is a small nation in Southeast Asia, having a population of 31.7 million in 2016. The population is expected to climb to 32.1 million by 2017. The gross national product (GNP) was RM1.07.9 billion while the per capita GNP in 2016 was RM37.738 (Bank Negara Malaysia, 2016). 
INTERNATIONAL JOURNAL OF ACADEMIC RESEARCH IN BUSINESS AND SOCIAL SCIENCES Vol. 10, No. 9, 2020, E-ISSN: 2222-6990 @ 2020 HRMARS

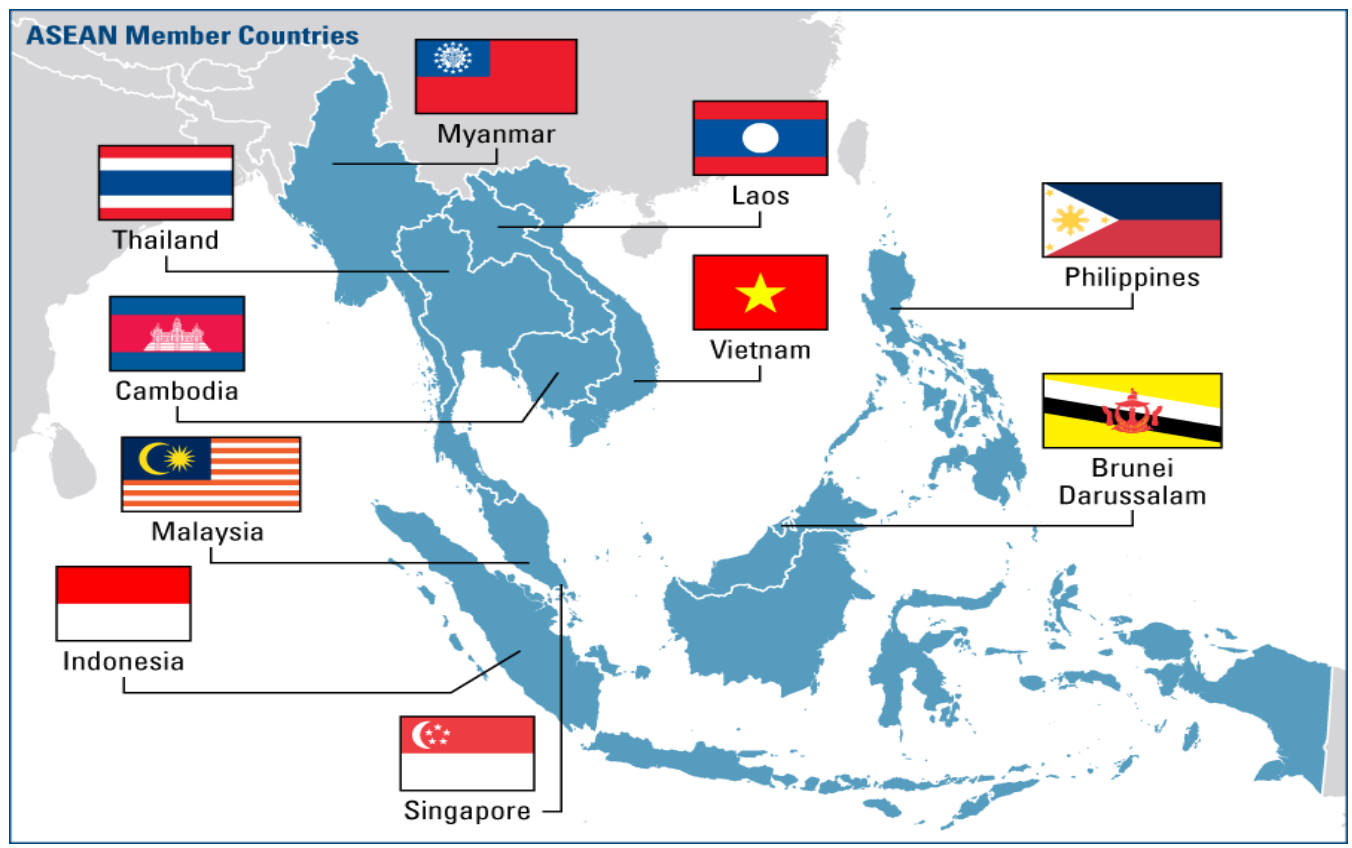

Figure 1: Map of Southeast Asian Countries

On the whole, the development of Malaysia is ahead of other ASEAN nations. Even though the GDP of Malaysia lags behind that of Indonesia and Thailand, Malaysia's per capita income lags behind only to Singapore, making Malaysia a competitive nation together with other developed nations. Table 1 shows the per capita income of Malaysia and other ASEAN nations in Southeast Asia.

Table 1. GDP and GDP Per Capita of Southeast Asian Nations, 2016

\begin{tabular}{lcc}
\hline \multicolumn{1}{c}{ ASEAN } & $\begin{array}{c}\text { Gross domestic product } \\
\text { (USD million) }\end{array}$ & GDP per capita (USD) \\
\hline Indonesia & 861,934 & $3,346.50$ \\
Thailand & 395,168 & $5,814.80$ \\
Malaysia & 296,283 & $9,768.30$ \\
Singapore & 292,739 & $52,888.70$ \\
Philippines & 292,451 & $2,904.20$ \\
Viet Nam & 193,599 & $2,110.90$ \\
Myanmar & 62,601 & $1,161.50$ \\
Cambodia & 18,050 & $1,158.70$ \\
Brunei Darussalam & 12,930 & $30,554.70$ \\
Lao PDR & 12,369 & $1,818.40$ \\
\hline
\end{tabular}

Notes. Adapted from World Bank Report, 2017

For comparison, Indonesia achieved its independence from the Dutch on 17 August 1945, earlier than Malaysia which achieved independence on 31 August 1957. However, the development of Malaysia is found to be ahead, in terms of its per capita income. 
INTERNATIONAL JOURNAL OF ACADEMIC RESEARCH IN BUSINESS AND SOCIAL SCIENCES Vol. 10, No. 9, 2020, E-ISSN: 2222-6990 @ 2020 HRMARS

According to World Bank (2014), Indonesia has experienced rapid growth in its economic sector. This situation has enabled it to reduce the poverty rate among its citizens. The success of reducing its poverty rate from $24 \%$ in 1999 to $11.4 \%$ in 2013 is the testimony that reduction of the poverty rate has occurred. However, according the World Bank (2013), the reduction that has occurred was still slow. Although it has been able to reduce poverty, 65 million (25.9\%) of its citizens out of 251.3 million who were above the poverty line face a risk that they might return to be poor again.

The situation in Singapore is very different. Although Singapore was originally a part of Malaysia, separated from Malaysia on 9 August 1965, Singapore is found to be further ahead in the development of its economy. Even though Singapore's national GDP is lower compared with Indonesia, Thailand and Malaysia, its per capita income (USD52,888.70) is higher than that of Brunei Darussalam, a small nation which earned its wealth from oil, with a per capita income of USD30,554.70. Overall, based on the ranking statistics of 188 nations recorded by the UNDP (2016), Malaysia was ranked 59th as shown in Table 2, as follows.

Table 2. Human Development Index (HDI) of ASEAN Nations 2015

\begin{tabular}{lcc}
\hline \multicolumn{1}{c}{ Country } & $\begin{array}{c}\text { Human } \\
\text { Development Index } \\
\text { (HDI) 2015 }\end{array}$ & World Ranking \\
\hline Singapore & 0.925 & 5 \\
Brunei Darussalam & 0.865 & 30 \\
Malaysia & 0.789 & 59 \\
Thailand & 0.740 & 87 \\
Indonesia & 0.689 & 113 \\
Viet Nam & 0.683 & 115 \\
Philippines & 0.682 & 116 \\
Lao People's Democratic Republic & 0.586 & 138 \\
Cambodia & 0.563 & 143 \\
Myanmar & 0.556 & 145 \\
\hline
\end{tabular}

Note. Adapted from UNDP (2016)

The success of Malaysia in enhancing its place in the world 's eyes is expressed as Malaysia makes every effort to achieve its status as a developed nation by 2020 (EPU, 2017a). Therefore, Malaysia has designed its development policy in the Eleventh Malaysia Plan 2016-2020 by striving for inclusive development for its citizens in its effort to achieve the status of a high-income developed nation (EPU, 2017b).

Among the government's aspirations in the inclusive development is to increase the incomes of those households earning RM3,860 and below, or better known as the B40, to enable them to move into the middleclass society earning in the range of $\mathrm{RM} 3,860$ to RM8,319. This group is better known as the B40 households. The main purpose is to solve the problems of escalating costs of living which is putting pressure on the B40 group (Abdullah, 2017). 
INTERNATIONAL JOURNAL OF ACADEMIC RESEARCH IN BUSINESS AND SOCIAL SCIENCES Vol. 10, No. 9, 2020, E-ISSN: 2222-6990 @ 2020 HRMARS

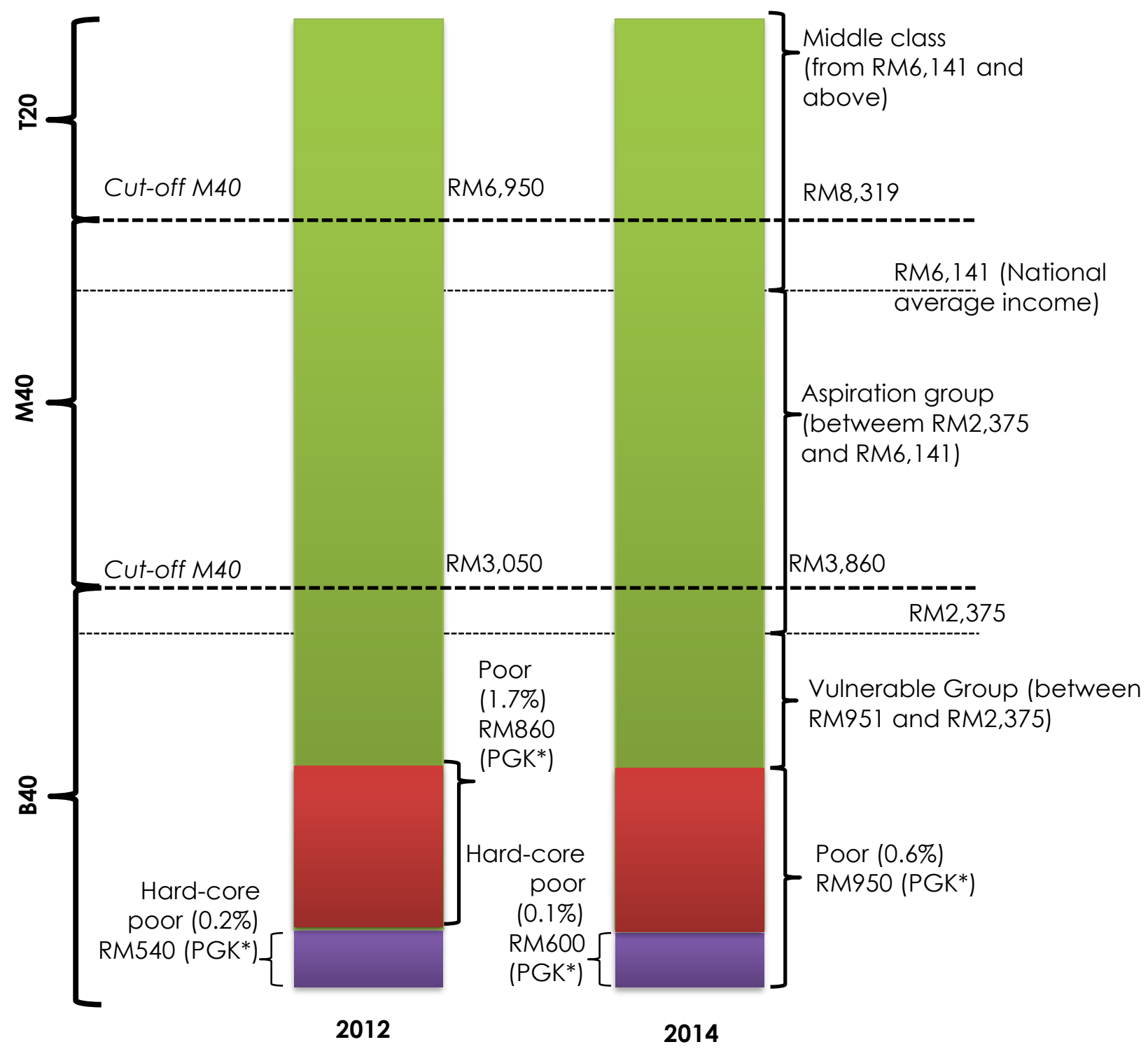

Figure 1. The structure of household income groups, Malaysia, 2012 and 2014. Adapted from Fairul Fafieq Abdullah (2017).

Note. ${ }^{*}$ PGK $=$ Poverty line income

\section{The 1AZAM Programme}

The 1AZAM programme was introduced by the Central Government of Malaysia to bring the poor population out of the shackles of poverty. The programme has been given a new brand name from its original programme, which was Income Increasing Programme. The word AZAM itself is an acronym for "Ending the Era of Poverty" in the Malay Language. The participants were selected from the eKasih Database, the database for poor citizens in Malaysia.

Indirectly, the initiative also benefits with their own attempts to push the disadvantaged classes out of the disadvantaged fetters. The Ministry of Women, Family and Community Development (KPWKM) is the responsible ministry leading the programme. Other ministries also involved in the programme 
are the Ministry of Agriculture and Agro-Based Industries, the Ministry of Human Resources (KSM), the Ministry of Agriculture and Family Development Sarawak (KKWPK), Ministry of Urban Wellbeing, Housing and Local Government and Amanah Ikhtiar Malaysia (AIM). Five programmes are implemented under the 1AZAM programme, namely Aim Works (AZAM Kerja), Aim Agriculture (AZAM Tani), Aim Business (AZAM Niaga), Aim City (AZAM Bandar), and Aim Services (AZAM Khidmat) (Nor \& Azhar, 2016). However, 1AZAM programmes are also implemented in Sabah and Sarawak by their respective state governments.

The initiative, initiated in 2010, was completely implemented in 2011, with the goal of generating economic incentives to improve low-income household productivity. The programme was based on the concept of entrepreneurship, and using the welfare approach to maximise individual potentials based on the skills or interest of the individuals (Razid, 2013). AZAM Tani, was implemented by providing agriculture equipment, livestock, agriculture inputs under the Ministry of Agriculture and Agro-Based industries (KPIAT). The KPIAT also provides advisory services, guidance and training to the participants.

The Ministry of Women, Family and Community Development (KPWKM) offers the selected participants 21 packages via AZAM Niaga. The National Welfare Foundation (Yayasan, YKN) is the implementation agency for KPWKM. The participants will be provided with resources according to their needs under this programme, as shown in Table 3.

Table 3. Agriculture and agro-based projects under AZAM Tani 's programme

\begin{tabular}{|c|c|}
\hline Sector & Project Type \\
\hline Plantation & $\begin{array}{l}\text { Short-Term Plantation-corn, melons, mushrooms, chili and } \\
\text { fertigation. }\end{array}$ \\
\hline Fishing & $\begin{array}{l}\text { Catfish, ornamental fish, fishing equipment, Fish farming in } \\
\text { cages, breeding freshwater fish and shrimp farming. }\end{array}$ \\
\hline Livestock & Swallow, honeybees, ducks and chickens. \\
\hline Processing & $\begin{array}{l}\text { Cake, dried fish, crackers, salted fish, traditional snacks, frozen } \\
\text { foods, sauces, chips, drinks and juice, salted eggs, coconut } \\
\text { milk, coconut paste and coconut jelly. }\end{array}$ \\
\hline Product Business & $\begin{array}{l}\text { Selling sugarcane juice, soy products, fruits - sliced fruit, fried } \\
\text { bananas, crackers, nasi lemak, roti canai, kebab and fresh fish. }\end{array}$ \\
\hline Facilities/Equipment & Mobile kiosk, booth, three-wheel motorcycle. \\
\hline Services & Lawn mower, poison spray, tractors, seed sprayers. \\
\hline Handicrafts & Handicrafts, seafood, shells, artificial bait for fishing. \\
\hline
\end{tabular}

Gradually, the guidance provided to the participants through this programme is expected to not only move them out of the shackles of poverty, but also to enable them to become competitive. This occurred when the Ministry of Women, Family and Community Development (KPWKM) found some of them able to progress further. Realising this fact, the participants are provided with extra aid in the 1AZAM programme. The help comes from the programme known as "Beyond 1AZAM" (Beyond 1AZAM programme, 2014). 
INTERNATIONAL JOURNAL OF ACADEMIC RESEARCH IN BUSINESS AND SOCIAL SCIENCES Vol. 10, No. 9, 2020, E-ISSN: 2222-6990 @ 2020 HRMARS

\section{The Challenges in Managing the 1AZAM Programme}

The 1AZAM program was initiated by Malaysia 's central government to push its poor people out of the fetters of poverty through their own efforts. This initiative was undertaken by the government to move the poverty groups out from the shackles of poverty and make them able to become competitive. Indirectly, a small rise in income, that is, RM300, relative to their earlier income, is seen as a reasonable starting point with the expectation that they will step out of the poverty trappings at some stage in the future.

However, since its introduction in 2010, there have been many issues surrounding the programme. According to a report by Public Accounts Committee presented in the 13th session of the Malaysian Parliament, on 24 March 2015, nine issues were raised during the session. The nine issues were as follows:

\section{Participants not Selected through the Ekasih Database.}

Based on the National Audit Department's censorship, it was not known the status of 58 per cent or 58 participants taken as the study sample. There were in fact participants whose data had not been put into the eKasih database. This means that the selection system used was not completely selected via the eKasih database, although participants were identified in the eKasih database to be selected via.

\section{No Standard Operating Procedure (SSOP) for Selecting Material Suppliers}

The method of selecting the 22 suppliers of goods to the 1AZAM programme, involving expenditures of RM8 million, could not be ascertained because no SOP was prepared for selecting the suppliers.

\section{Participants not Using Equipment Supplied}

The study also revealed that 64 out of 265 participants did not make use of the equipment that was provided to them, effectively wasting expenditure on these equipment.

\section{Some Participants Cannot Be Found}

National Audit Department Malaysia also studied 370 participants, by visiting their homes to conduct a physical study on them. The physical study aimed to see the development of the participants after they have received the aid allocated to them. However, from the 370 participants, 33 participants could not be found.

\section{Late in the Opening the 1AZAM Special Account}

The National Welfare Foundation (YKN) under the Ministry of Women, Family and Community Development was the implementer of 1AZAM programme took too long to create the 1AZAM special account. They only opened the special account on 19 September 2014 by depositing RM5.51 million from the RM165.51 million allocated for 1AZAM system into a current account at the Islamic Alliance bank. The majority of the fund had been invested in ten local banks with fixed deposit accounts. The delay in opening the account 1AZAM could not have been attributed to system starting in 2010 .

\section{Group Projects have not yet Generated any Incomes}

Three out of five sample projects operated by the Ministry of Agriculture and Agri-based Industry have not yet been able to produce income; and 278 participants were active in these group projects. 
INTERNATIONAL JOURNAL OF ACADEMIC RESEARCH IN BUSINESS AND SOCIAL SCIENCES Vol. 10, No. 9, 2020, E-ISSN: 2222-6990 @ 2020 HRMARS

\section{Management of Participants' Goods}

The National Audit Department also conducted a study by selecting four suppliers to the 1AZAM participants from 19 suppliers of the goods. Specific records reviewed by the auditor found that the suppliers' transactions lacked clarity on several items. In two aspects the dubious transactions can be seen as follows:

\section{No Price Details of the Goods Received by the Participants}

The applicants are eligible to obtain an allowance of RM5,000 according to the 1AZAM programme. Nevertheless, in the packets that the participants received, the KPWKM and YKN did not decide a price estimate in specifics for the equipment components. This has contributed to the presentation of 23 quotations worth RM8 million by 22 suppliers without specifying the prices of the equipment components in each kit. The rates offered were based upon each package's lump sum amount.

\section{Suppliers' Scope of Services}

The National Audit Department also found no evidence to show that the participants have used the equipment supplied by the suppliers as should be. Eight out of 10 respondents personally indicated that the pieces of equipment they got were not long-lasting; they were easily damaged, and so on. In addition, two participants reported that they received ovens to burn cakes, which could not be used because the electricity voltage supply did not fit the voltage requirement of the oven they received.

\section{Methodology of the Study}

Despite the feedbacks received and actions taken by the Ministry to maximise productivity of the programme, these problems still keep on occurring. This present study was done on 100 participants of the 1AZAM programme around Penang, using the random sampling technique. The list of names was obtained from the People's Welfare Division, Implementation and Coordination Unit, Prime Minister's Department on October 2015 (Nadiha \& Radieah, 2016).

Data were obtained from the interviews conducted with the Distribution Division, Economic Planning Unit, Prime Minister's Department on January 2017 and the interviews conducted with People's Welfare Division, Implementation and Coordination Unit, Prime Minister's Department on October 2015. These two government departments have been consulted, as they are responsible for the program implementation. Then the findings of these open interviews were analyzed using textual analysis to clarify the implications of all the problems and their consequences for the implementation of the 1AZAM programme.

This study also used the Auditor General Report (2016) as the principal reference. Interviews ( $N=100)$ were also conducted to see the development of Program participants around Penang as the Auditor General 's scope of investigation did not include Penang participants. For the open interviews, the random sampling approach was used to pick participants. This was based on the qualitative data obtained from Implementation and Coordination Unit, Prime Minister's Department, on September 2015.

All data of the 1AZAM participants were obtained from the Implementation and Coordination Unit, Prime Minister's Department through the eKasih database. To improve poverty management in Malaysia, the government has introduced the eKasih system, which is the National Poverty Data Bank, a national-level database system of poor households to assist in the planning, implementation and monitoring of poverty programs implemented by the government agencies involved. EKasih was 
INTERNATIONAL JOURNAL OF ACADEMIC RESEARCH IN BUSINESS AND SOCIAL SCIENCES Vol. 10, No. 9, 2020, E-ISSN: 2222-6990 @ 2020 HRMARS

created following the result of the meeting of the Council of Ministers held on 31 October 2007 and the meeting of Menteris Besar and Chief Ministers held on 1 November 2007. From the results of the meetings, the eKasih system was developed in-house by the Implementation and Coordination Unit, Prime Minister's Department (ICU JPM) and the system started to be used on June 2008 (PPPN, Perak, 2015).

\section{Findings And Analysis of Study Results}

Based on the statement of problems that have been discussed before this, most of the problems originated from a disorganised system of management. Other than that, those issues have impacted the program's success. Even under these circumstances, there are participants in the 1 AZAM programme, and through the program they are able to come out of the shackles of poverty. This occurs when they put in all their efforts to bring about positive effect to those who really use the programme to their benefits (Auditor General, 2016).

The main focus of this analysis is on the difficulties and barriers that the programs implementing parties face. Based on the 100 participants interviewed from a total of 3,176 participants in the whole of Penang State enlisted in the eKasih data, the findings are as follows:

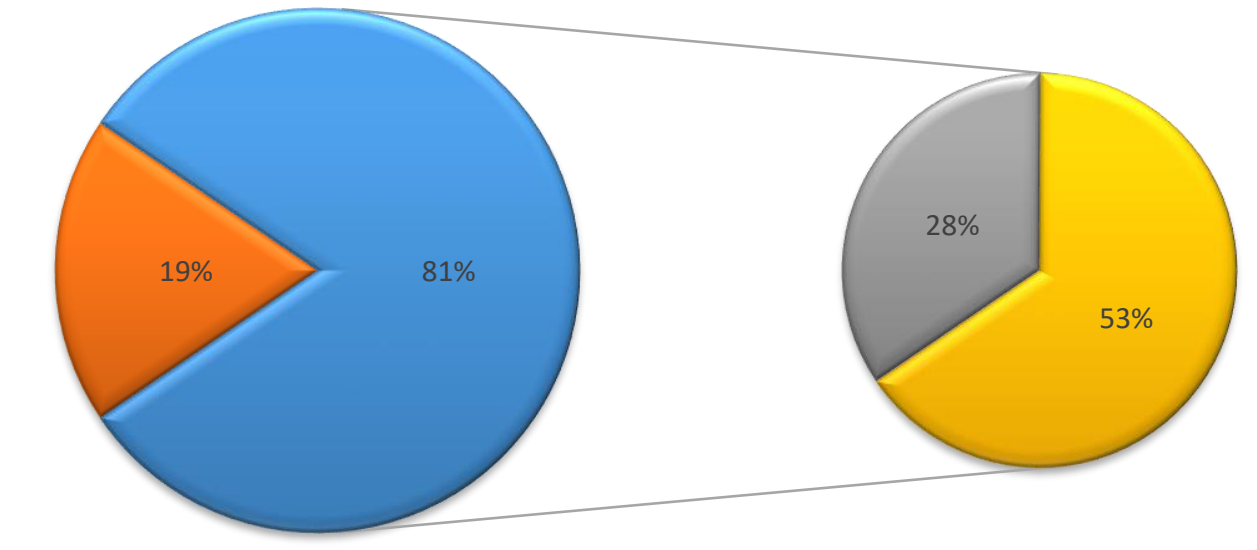

- Participants can be traced based on the data provided

$\square$ Participants who cannot be detected even if their data is in the system

口Did not make the application but the data indicates that the participant made the application

$\square$ Participants

Figure 2: Study results on the samples enlisted as aid recipients of 1AZAM

\section{Main Performance Index Set Lower than Poverty Line Income (PGK)}

Based on the AZAM Niaga programme, from 195,953 participants recorded as of October 2016, a total of 93,469 participants have successfully increased their incomes (Azizah Mohd, 2016). This implies that only $47.7 \%$ of the participants have been successful in increasing their incomes. More worrying is the fact that the Key Performance Index (KPI) was an increase of RM300 in any three months to determine the success of programme (PEMANDU, 2015). The reported KPI cannot actually reach the Poverty Income Line (PGK) set at RM950. This situation is very different from the National 
INTERNATIONAL JOURNAL OF ACADEMIC RESEARCH IN BUSINESS AND SOCIAL SCIENCES Vol. 10, No. 9, 2020, E-ISSN: 2222-6990 @ 2020 HRMARS

Poverty Line Income level that was set at RM950 (Fairul Fafieq Abdullah, 2017). The PGK is the level of income used to measure absolute poverty based on the minimum food requirement required by households and not the amount of food requirement by household members to live healthy and active (EPU, 2015).

Actually, this situation has big implication on the poverty statistics in Malaysia. This is because even though the participants may be recorded as having successful in going through programme, in fact they might not have necessarily cleared themselves from the poverty line income. Indirectly, these participants have not cleared and they are actually still in the shackles of poverty. This means that in terms of statistics they have successfully gone through the programme, it is still doubtful that they have achieved real success in terms of Malaysian poverty income line (PGK).

\section{Waste of Allocation Money}

Leakages occur at the lower level preventing the programme from achieving encouraging success. The government has chanelled a substantial number of resources to ensure the program's success was wasted. As reported in the Auditor General ( 2016), a RM1.45 billion allocation was expended during the 2011 to 2013 period. In addition, each participant has also received assistance worth between RM5,000 and RM10,00 in the form of equipment or soft capabilities to generate their economy.

Nevertheless, the allocation did not carry advantages to the participants as certain devices such as refrigerators, sewing machines, ice-cream machines broke down and didn't last long (Auditor General, 2016). Additionally, 53 of them received the assistance based on interviews with 66 participants who applied for assistance, while 14 participants are still waiting to obtain their assistance.

Assistances to disabled participants were not befitting. Based on the interviews held, some of the blind participants were given equipment for making cakes, such as ovens, kneading machines and the like, whereas these people cannot make use of these machines properly. Respondents also revealed that the oven given to them were defective upon receipt of the equipment; they have tried to repair them but without success. Although, they have reported about the defective machines, no actions have been taken.

Furthermore, input from one participant also revealed that she had received two sewing machines, one for straight sewing and one for hem stitching to help her continue as a tailor. Nevertheless, one of the machines, the hem stitching machine could not be used as the quality was too low, and suitable only for learning purposes. This situation has caused her to bear the cost of hem stitching as she has to send the ham stitching to another shop because she did not have a good hem stitching machine. There was also something very shocking when the recipient received a donation on the aid in the form of ASTRO Njoi, though such equipment does not help generating any income at all because it is a free satellite television service in Malaysia. He asked for a boat engine to help him fish at sea but, according to the receiver, he did not get what he was looking for.

\section{The eKasih System Needs to be Upgraded}

The National Poverty Database or best known as eKasih is a program that preserves data about disadvantaged Malaysian people (ICU, 2016). Records on poverty in eKasih system are as follows:

a. Individual Profile whether Household head (KIR) or Members of Household (AIR) are recorded together. 
INTERNATIONAL JOURNAL OF ACADEMIC RESEARCH IN BUSINESS AND SOCIAL SCIENCES

Vol. 10, No. 9, 2020, E-ISSN: 2222-6990 @ 2020 HRMARS

b. Household address.

c. Education

d. Skills and Occupation

e. Possession of assets

f. Health status

g. Income

h. Type of aid received

i. Helping agency

j. Status of aid application

k. Status of programme or aid effectiveness

Among the main characteristics of eKasih are as follows:

a. Online reviewing of poverty status

b. Coordination of aid information

c. Online updating of poverty information

d. Automatic calculation of poverty status (poor/hard core poor) based on Poverty Line Income (PGK) per capita

e. Generation of reports and statistics on poverty

f. Poverty mapping and monitoring

The study conducted on the eKasih system, which is Malaysia 's poor population database system, revealed that the system needs upgrading because many poor Malaysian citizens have not registered under the eKasih. Indirectly, the eKasih scheme does not mirror the true image of a poor group in Malaysia.

At present, individuals who are enrolled in the system are based on the initiative of the village committee and local government members, such as representatives of the Legislative Council Area (ADUN) and others. The total number of poor communities recorded in the eKasih system will be affected unless the village council, ADUN, and so forth are not involved.

By right, the eKasih system can be updated automatically without any third party registration since the government has a database system in the Inland Revenue Board (LHDN) that relates to the individual income. Besides collecting taxes, the LHDN is entrusted to present aid money known as Citizens' Relief 1Malaysi or BRIM. The government can actually track poor households or individuals in Malaysia via tax collection and BR1M. According to Yaacob (2015), however, not all poor Malaysian people consent to be enrolled in the scheme. Thus, the persons mentioned in the system are those who choose to register their names.

It's very interesting to see that some participants listed in the eKasih did not know that the program listed their names. The results of the interview showed that 10 participants did not even know about the 1AZAM program, therefore they did not know that their names had been registered as shown in Figure 2. This also suggests that since the 1AZAM program participants were chosen based on the names enlisted in the eKasih, they also did not know about the eKasih system. This finding is very worrying because it is proof that the poor population are not sensitive about their personal data and their personal identity being used at liberty by others without their approval. It is also very worrying that their personal information could be used by others for cybercrimes and other criminal purposes. 


\section{Monitoring Method Not Holistic}

The interviews held with participants selected using random sampling in the whole of Penang, found that the monitoring by the authoritative agencies were not holistic with regard to the participants of the 1 AZAM programme. Some participants disclosed that they were have never been monitored throughout the period they were receiving their aid, whereas information from the implementers of the 1AZAM explained that interviews would be conducted with the participants, and physical visits would be conducted to verify the development of every participant. When this issue was brought to the attention of the Distribution Section, ICU JPM, they said that they already knew about the constraints faced by the programme. They said that this issue occurred because they did not have enough staff to monitor the 1AZAM participants. Therefore, some participants were left out and not monitored. However, they are taking steps to improve the situation because the programme could be the best platform to eradicate poverty and to achieve the status of a high income developed nation.

\section{Conclusion}

The 1AZAM programme has a big potential to pave the way for the poor groups in Malaysia to increase their incomes. In fact, the results of the interviews with 100 respondents showed that 17 of them were single mothers. Therefore, the programme could at least help this group to raise their incomes. However, much effort is still needed to streamline and improve the programme to enable the participants of this programme to achieve maximum success.

The problems faced by the 1AZAM programme are more of technical and management problems. These problems have reduced the impact of the programme on the poverty group and have made it to become mediocre. In terms of the planning, the programme clearly has a great potential to help the people to move themselves out of the shackles of poverty and become a competitive community. Therefore, the programme improvement needs to be implemented as soon as possible because the time for the country to achieve the status of a high income developed nation is becoming very short.

\section{Acknowledgement}

This paper is a part of a research funded by Short Term Grant (304/PCGSS/6313184) and Research University Grant (1001/PCGSS/816308) awarded by Universiti Sains Malaysia. The writers wish to express their heartiest gratitude to all other parties who have been involved either directly or indirectly in this research.

\section{References}

Mohd, A. (2016). Official statement Parliament Malaysia, Parliament Hansard, Dewan Rakyat, Parlimen Ketiga Belas.

Bank Negara. (2016). Economic recession of the year 2016. Retrieved from www.bnm.gov.my/files/publication/ar/bm/2016/cp01.pdf

Beyond 1AZAM programme. (2014). The New Straits Times. Retrieved from http://www.nst.com.my/news/2015/09/beyond-1azam-programme-successful-1azamparticipants

Abdullah, F.F. (2017) Program 1AZAM, B40 and eKasih feedback from the Distribution Section, Economic Planning Unit, Prime Minister's Department [Interview]. 
INTERNATIONAL JOURNAL OF ACADEMIC RESEARCH IN BUSINESS AND SOCIAL SCIENCES

Vol. 10, No. 9, 2020, E-ISSN: 2222-6990 @ 2020 HRMARS

Chief Auditor General. (2016). Laporan jawatankuasa kira-kira wang negara (PAC) parlimen berhubung pengurusan Program 1AZAM oleh Kementerian Pembangunan Wanita, Keluarga dan Masyarakat. Kuala Lumpur: Dewan Rakyat Ketiga Belas Penggal Keempat.

Yaacob, I. (2015) Program 1AZAM, B40 and eKasih are feedback from the People's Welfare Division, Implementation Coordination Unit, Prime Minister's Department. [Interview].

Malaysia, Economic Planning Unit. (2015). Eleventh Malaysia Plan. Putrajaya: The Prime Minister's Department.

Malaysia, Economic Planning Unit. (2017a). Vision 2020. Retrieved from http://www.epu.gov.my/en/development-policies/vision-2020

Malaysia, Economic Planning Unit. (2017b). Eleventh Malaysia Plan. Retrieved from http://www.epu.gov.my/en/rmk/eleventh-malaysia-plan-2016-2020

Malaysia, Implementation Coordination Unit. (2016). eKasih info. Retrieved from https://ekasih.icu.gov.my/Pages/InfoeKasih.aspx

Razid, M. A. A. (2013). Kejayaan Malaysia dalam program basmi kemiskinan. Putrajaya: Jabatan Penerangan Malaysia.

Nadiha \& Radieah. (2016). 1AZAM program implementation in Penang, Malaysia: Towards poverty eradication. Paper presented at the International Conference on Sustainable Development Goals (ICSDG2016). South East Asia Sustainability Network (SEASN) on 7-8 Disember 2016 at Universiti Sains Malaysia.

Nor, R., \& Azhar, S. (2016). 1AZAM aiding low-income households in Malaysia. Journal of Human Resource and Sustainability Studies, 4(4), 293-304. doi: 10.4236/jhrss.2016.44029.

Pejabat Pembangunan Persekutuan Negeri Perak. FAQ Permohonan Bantuan E-Kasih. (2015). Retrieved from http://www.prk.icu.gov.my/v3/index. php/layout1/ 252.

PEMANDU, Performance Management and Implementation Unit. (2015). GTP: Government transformation program: Annual report 2014. Putrajaya: Performance Management and Implementation Unit.

United Nation Development Programme. (2016). Human development index and its components. Retrieved from http://hdr.undp.org/en/composite/HDI

World Bank. (2017). GDP per capita (current US\$). Retrieved from http://data.worldbank.org/indicator/NY.GDP.PCAP.CD

World Bank. (2014). Reducing extreme poverty in Indonesia. Retrieved from http://www.worldbank.org/en/country/indonesia/brief/reducing-extreme-poverty-inindonesia 